\title{
Medical and
}

\section{Veterinary Entomology}

\section{2nd Edition}

\author{
by Dr D S Kettle, Department of Entomology, \\ University of Queensland, Australia
}

$\mathrm{T}$ he first edition of this book published in 1984 established itself internationally as a standard text in medical and veterinary entomology. This new edition retains the same overall aims and structure but has been thoroughly revised to take account of new advances in the subject.

The main focus of the book is on the general biology of insects and the Acari (mites and ticks) of medical and veterinary importance, together with a brief description of their taxonomy and the treatment of diseases they cause.

The book is divided into three parts: The first provides a general introduction to the classification, structure and function of the relevant insects and Acari; the second covers in seventeen chapters, the main groups of insects and acarines of medical and veterinary importance from the Culicidae (mosquitoes) to the Ixodidae (hard ticks); part three then provides an overview of those diseases of which the pathogens are transmitted by insects or acarines. The book will continue to serve as a major reference text for students taking courses in zoology, tropical medicine, veterinary science, entomology and parasitology, as well as for professionals working in both pure and applied entomology.

Published October 1995 c.750 pages

Published in Hardback and Paperback

ISBN 0851989683 (HB) approx $£ 75.00$

ISBN 0851989691 (PB) approx $\mathfrak{3 7 . 5 0}$

To place your order for Medical and Veterinary Entomology 2nd Edition, contact: Book Sales Department, CAB INTERNATIONAL, Wallingford, OXON OX10 8DE, UK Tel: +44 0 (1491) 832111 Fax: +44 0 (1491) 826090 e-mail: cabi@cabi.org 


\title{
The Scale Insect Family Coccidae: An Identification Manual to Genera
}

\author{
C J Hodgson, Department of Biological Sciences, \\ Wye College, University of London, UK
}

$\mathrm{T}$ he soft-scales (Coccidae) are one of about 20 families of the scale insect super-family Coccoidea. The females are all sap-sucking and all 1100 known species are potential pests in agriculture, horticulture or forestry. This family is amongst the most poorly known although the third largest in the superfamily. This book discusses all known genera and redescribes and illustrates the adult females of the type species of about 160 soft scale genera. No previous revision has covered all world genera. On the basis of this study a new classification of the soft-scales is introduced based on both male and female characters and keys are provided to the identification of the type species (females) of each genus. An introductory chapter describes the basic structure and introduces the terminology. As the females of all Coccoidea are of potential economic importance, this book will be of value to any entomologist who needs to identify soft-scales either for quarantine or for research involving natural enemies for biological control.

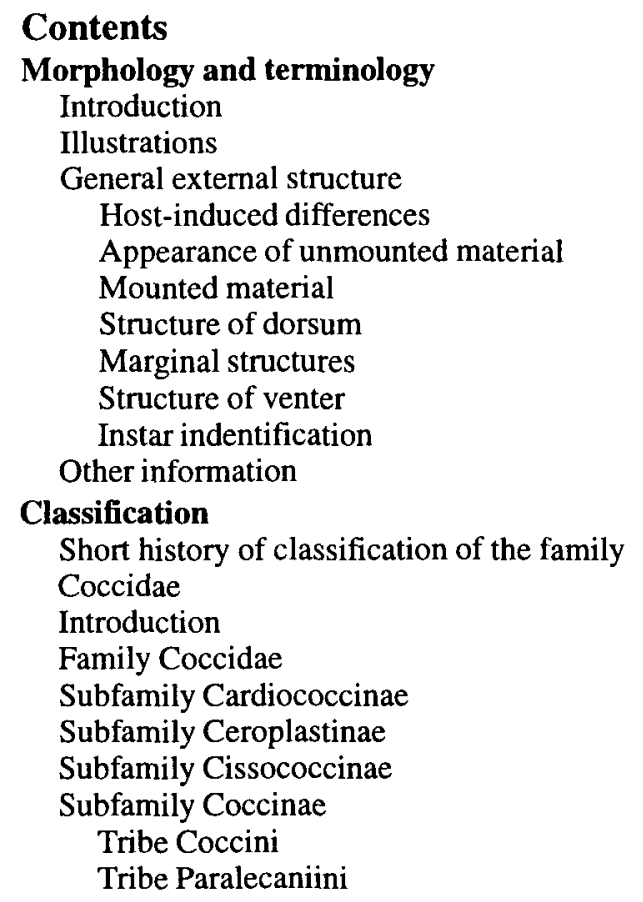

\author{
Tribe Pulvinariini \\ Tribe Saissetiini \\ Subfamily Cyphococcinae \\ Subfamily Eulecaniinae \\ Subfamilies Eriopeltinae and Filippiinae \\ Subfamily Myzolecaniinae \\ Subfamily Pseudopulvinariinae \\ Unplaced Genera
}

List of genera and type species

Keys to subfamilies, tribes and genera Key to subfamilies and tribes

Key to genera in the Cardiococcinae

Key to genera in the Ceroplastinae

Key to genera in the Coccini

Key to genera in the Paralecaniini

Key to genera in the Pulvinariini

Key to genera in the Saissetiini

Key to genera in the Cyphococcinae

Key to genera in the Eulecaniinae

Key to genera in the Eriopeltinae + Filippiinae

Key to genera in the Myzolecaniinae

Descriptions of type species

April $1994 \quad 672$ pages Hardback ISBN 0851988822

Price: $£ 75.00$ (US\$125.00 Americas only)

To place your order contact:

Book Sales Department, CAB INTERNATIONAL, Wallingford, OXON OX10 8DE, UK

Tel: +44 0 (1491) 832111 Fax: +44 0 (1491) 826090 e-mail: cabi@cabi.org 


\title{
Insect Pests and Fresh Horticultural Products: Treatments and Responses
}

\author{
Edited by R E Paull, University of Hawaii, and \\ J W Armstrong, USDA Tropical Fruit and Vegetable \\ Research Laboratory, Hawaii, USA
}

$\mathrm{P}$ ostharvest treatments are required to disinfest fruits, vegetables, nuts, flowers and ornamental plants of quarantined insects prior to export. These insect pests, such as various ephritid fruit flies, are of quarantine importance because either they are absent from the importing country or that country has a zero tolerance for all live insects. This book considers the various treatment technologies and strategies and the effect that these have on the insects and the produce. Treatments include the promotion of pest-free zones and natural resistance, and the use of fumigation, irradiation, insecticides, extremes of temperature, controlled or modified atmospheres, and combinations of these. Current research, directed at prolonging postharvest life of the commodity and maintaining its quality, is thoroughly assessed through detailed reviews of the literature. The book is a comprehensive work directed at academics and research workers in entomology and horticulture, as well as quarantine officers.

\section{Contents}

Foreword, JM Lyons

Introduction, $R E$ Paull, $J W$ Armstrong

Part I Quarantine Criteria

Part II Physiological and Biochemical Responses of Insects to Possible Disinfestation Procedures

Part III Product Physiological and Biochemical Response to Possible Disinfestation Procedures

Part IV Individual Product Treatments

April $1994 \quad 368$ pages Hardback ISBN 0851988725

Price: $£ 49.95$ (US $\$ 85.00$ Americas only)

To place your order contact:

Book Sales Department, CAB INTERNATIONAL, Wallingford, OXON OX10 8DE, UK

Tel: +44 0 (1491) 832111 Fax: +44 0 (1491) 826090 e-mail: cabi@cabi.org 


\section{NOTES FOR AUTHORS}

The Bulletin of Entomological Research publishes original research papers concerning insects, mites, ticks or other arthropods of economic importance in agriculture, forestry, stored products, biological control, medicine, animal health and natural resource management. The geographical scope of the Bulletin is worldwide but with emphasis on the tropics. Taxonomic papers are accepted if relevant. Short review papers, although normally by invitation, will also be considered for publication.

Page Format. The Bulletin is printed in a two-column format (column width of $80 \mathrm{~mm}$ ) with a text area of $170 \times 225 \mathrm{~mm}$.

Text. Papers should be typed, on one side of the paper only, with double line spacing and ample margins (at least $1.5 \mathrm{~cm}$ ) on each side and with no underlining or bold in text except for scientific names. Draft quality print from a word-processor is not acceptable. Standard abbreviations (e.g. fig. and figs) and metric units must be used. Guidelines for taxonomic papers are available.

When the paper has been accepted word-processed text stored on floppy disk is encouraged, providing the software is IBM/DOS compatible, but floppy discs must be accompanied by a hard copy. This will enable papers to be handled rapidly, and with fewer type-setting errors.

Abstract. Each paper must commence with a carefully prepared, accurate, informative abstract, in one paragraph, that is complete in itself and intelligible without reference to text or figures. It should not exceed 250 words. A short title should be provided as a running head.

Tables. Tables should be reduced to the simplest form, and should not be used where text or illustrations give the same information. They should be submitted on separate sheets at the end of the article and must fit conveniently into single column, full width or landscape (if absolutely necessary) format. Table captions should be typed on a separate sheet.

Illustrations. Copies only of artwork should be submitted. The original illustrations should accompany the paper after acceptance and revision. Text figures, line drawings, computer-generated figures and graphs should be of sufficient size and quality to allow for reduction by half or two-thirds. Half-tone photographs are acceptable where they are a real contribution to the text. Figure and captions should be typed on a separate sheet in the following format:

Figs 23-26. Figs 23-24, Urophora eggs: 23, U. hispanica; 24 , U. stigma. Figs 25-26, spermathecae: 25, U. maura; 26, U. stigma; scale lines $=0.05 \mathrm{~mm}$

Voucher specimens. The deposition of voucher specimens should be considered where appropriate.

References. References must be based on the name and year system, give full journal titles and conform to the following styles:

Powell, W. (1986) Enhancing parasitoid activity in crops. pp. 319-340 in Waage, J. \& Greathead, D. (Eds) Insect parasitoids. London, Academic Press (Symposium, Royal Entomological Society of London No. 13).

Southwood, T.R.E. (1978) Ecological methods with particular reference to the study of insect populations. 2nd edn. 524 pp. London, Chapman \& Hall

Zhou, X., Carter, N. \& Mumford, J. (1989) A simulation model describing the population dynamics and damage potential of the rose grain aphid, Metopolophium dirhodum (Walker) (Hemiptera: Aphididae), in the UK. Bulletin of Entomological Research 79, 373-380.

Citation of authors in the text should appear in the form: Polaszek (1990) or (Polaszek, 1990). More than one author should be cited in chronological order as: (Holloway et al., 1987; Walker \& Huddleston, 1988).

Offprints. 50 copies of each paper are provided free to the author (or major author) of each paper. Further copies may be obtained on payment, and the number required should be specified and ordered at proof stage.

Manuscripts. Three copies of the manuscript and artwork should be submitted to:

The Editor

Bulletin of Entomological Research

International Institute of Entomology

56, Queen's Gate

London

SW7 5JR, UK. 


\section{Bulletin of Entomological Research}

Burt, P. J. A., Colvin, J. \& Smith, S. M. Remote sensing of rainfall by satellite as an aid to Oedaleus senegalensis (Orthoptera: Acrididae) control in the Sahel

Downham, M. C. A., McVeigh, L. J. \& Moawad, G. M. Field investigation of an attracticide control technique using the sex pheromone of the Egyptian cotton leafworm, Spodoptera littoralis (Lepidoptera: Noctuidae)

Eisemann, C. H. Orientation by gravid Australian sheep blowflies, Lucilia cuprina (Diptera: Calliphoridae), to fleece and synthetic chemical attractants in laboratory bioassays

Harvey, A. W. \& Mallya, G. A. Predicting the severity of Spodoptera exempta (Lepidoptera: Noctuidae) outbreak seasons in Tanzania.

Hattingh, V. \& Tate, B. Effects of field-weathered residues of insect growth regulators on some Coccinellidae (Coleoptera) of economic importance as biocontrol agents

Langley, P. A. Evaluation of the chitin synthesis inhibitor triflumuron for controlling the tsetse Glossina morsitans morsitans (Diptera: Glossinidae).

Leong, E. C. W. \& Ho, S. H. Life cycle of Liposcelis entomophila (Psocoptera: Liposcelididae) and a culturing regime for liposcelids

Marris, G. C. \& Edwards, J. P. The biology of the ectoparasitoid wasp Eulophus pennicornis (Hymenoptera: Eulophidae) on host larvae of the tomato moth, Lacanobia oleracea (Lepidoptera: Noctuidae)

Mohan, S., Mohan, S. \& Disney, R. H. L. A new species of scuttle fly (Diptera: Phoridae) that is a pest of oyster mushrooms (Agaricales: Pleurotaceae) in India.

Muhamad, R. \& Way, M. J. Relationships between feeding habits and fecundity of Helopeltis theivora (Hemiptera: Miridae) on cocoa.

Omwega, C. O., Kimani, S. W., Overholt, W. A. \& Ogol, C. K. P. O. Evidence of the establishment of Cotesia flavipes (Hymenoptera: Braconidae) in continental Africa

Pedata, P. A., Hunter, M. S., Godfray, H. C. J. \& Viggiani, G. The population dynamics of the white peach scale and its parasitoids in a mulberry orchard in Campania, Italy.

Smits, A., Coosemans, M., Van Bortel, W., Barutwanayo, M., Delacollette, Ch. Readjustment of the malaria vector control strategy in the Rusizi Valley, Burundi

Stevens, J. \& Wall, R. The use of random amplified polymorphic DNA (RAPD) analysis for studies of genetic variation in populations of the blowfly Lucilia sericata (Diptera: Calliphoridae) in southern England

Williams, C. T. Effects of plant age, leaf age and virus yellows infection on the population dynamics of Myzus persicae (Homoptera: Aphididae) on sugarbeet in field plots

Book Reviews

Index of Authors (Volume 85). without prior permission of the copyright owner. 